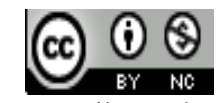

Jurnal Pendidikan Matematika Indonesia is licensed under

A Creative Commons Attribution-Non Commercial 4.0 International License.

\title{
Pengembangan Bahan AJAR Berbasis Keterampilan Metakognisi DALAM UPAYA MENINGKATKAN KEMAMPUAN LITERASI MATEMATIS MAHASISWA
}

\author{
Beni Setiawan $^{1)}$, Olenggius Jiran Dores ${ }^{2)}$ \\ 1) STKIP Persada Khatulistiwa, Sintang, Indonesia \\ E-mail: benisetiawan1892@gmail.com \\ 2) STKIP Persada Khatulistiwa, Sintang, Indonesia \\ E-mail: olenggius@gmail.com
}

\begin{abstract}
Abstrak. Bahan ajar berbasis keterampilan metakognisi adalah bahan ajar yang melibatkan kesadaran penggunanya dalam memikirkan tentang proses berpikir dalam hal melibatkan pengetahuan materi ajar sebelumnya sehingga kemampuan menalar, menyelesaikan masalah, representasi, koneksi atau disebut literasi matematis ini muncul. Tujuan penelitian ini adalah 1) mengembangkan bahan ajar berbasis keterampilan metakognisi; 2) mendeskripsikan peningkatan kemampuan literasi matematis mahasiswa. Penelitian ini menggunakan model pengembangan ADDIE. Kemudian teknik pengumpulan data yang digunakan adalah metode tes dan observasi untuk melihat peningkatan kemampuan literasi matematis. Analisis data dilakukan dengan uji gain score untuk mendapatkan hasil peningkatan kemampuan literasi matematis. Diperoleh kesimpulan bahwa 1) bahan ajar berbasis keterampilan metakognisi layak untuk digunakan; 2) berdasarkan validasi ahli secara keseluruhan bahan ajar berbasis keterampilan metakognisi dinyatakan layak untuk; 3) Terdapat peningkatan kemampuam literasi matematis mahasiswa sebesar 0,57 dengan kriteria sedang.
\end{abstract}

Kata kunci: pengembangan, keterampilan metakognisi, kemampuan literasi, mahasiswa.

\section{PENDAHULUAN}

PISA mendefinisikan literasi matematika merupakan kapasitas individu untuk memformulasikan, menggunakan, dan menafsirkan matematika dalam berbagai konteks (Mahdiansyah, 2014). Sari (2015) menjelaskan, literasi matematika merupakan kemampuan seseorang untuk merumuskan, menggunakan dan menafsirkan matematika dalam berbagai konteks masalah kehidupan sehari-hari secara efisien. Pada kemampuan tersebut matematika yang dimaksudkan mencakup seluruh konsep, prosedur, fakta dan alat matematika baik dari sisi perhitungan, angka maupun keruangan. Dari segi proses, kemampuan literasi tidak hanya terbatas pada kemampuan menghitung saja akan tetapi juga bagaimana mengkomunikasikan, menalar dan proses berfikir matematis lainnya.Dalam memunculkan kemampuan literasi matematis di kelas guru matematika dalam pembelajarannya hendaknya memperhatikan aspekaspek berikut: 1) pemodelan matematika, 2) memecahkan masalah, 3) mengembangkan kemampuan analitik dan logis, 4) mengembangkan abstraksi, 5) membangun kontekstual dan keterhubungan, 6) komunikasi (Murtiyasa, 2015).

Mahasiswa calon guru Sekolah Dasar (SD) yang nantinya akan mengajar matematika khususnya di kelas tinggi harus cukup mendapatkan kesempatan untuk mengembangkan kemampuan literasi matematisnya. Mengajarkan bagaimana menyelesaikan masalah merupakan kegiatan guru untuk memberikan tantangan atau motivasi kepada para siswa agar mereka mampu memahami masalah tersebut, tertarik untuk memecahkannya, mampu menggunakan semua pengetahuannya untuk merumuskan strategi dalam memecahkan masalah tersebut, melaksanakan strategi 
itu, dan menilai apakah jawabannya benar. Selanjutnya Prihandoko (dalam Setiawan, 2016) mengungkapkan selain memahami penalaran dalam matematika, seorang guru perlu melakukan analisis terhadap masalah penalaran yang ada dalam materi matematika SD serta bagaimana mengarahkan siswa untuk bernalar dengan benar.

Guru yang dimaksud harus memiliki kemampuan literasi matematis yang baik, hal ini berlaku juga kepada mahasiswa calon guru SD. Kenyataannya pada pembelajaran di kelas tidak semua mahasiswa dapat menunjukkan kemampaun literasi matematis yang baik. Hal ini ditemukan peneliti yang mengajar mata kuliah Konsep Dasar Matematika dan Pembelajaran Matematika SD. Dari hasil soal tes berbasis literasi matematis yang peneliti berikan sebanyak $76 \%$ mahasiswa nilainya di bawah 50. Berdasarkan hasil analisis mahasiswa cenderung kesulitan dalam mengerjakan soal pada kemampuan menalar, kemampuan representasi serta komunikasi matematis antar materi. Terlihat pada data, mahasiswa cenderung tidak melibatkan pengetahuan terdahulu yang telah dipelajarinya, dengan beralasan lupa, tidak paham materi sebelumnya dan sulit untuk mencari solusi dikarenakan tidak memahami soal. Hal ini dikarenakan mahasiswa tidak melibatkan kemampuan metakognisinya. Metakognisi termasuk dalam berpikir tingkat tinggi yang melibatkan kontrol aktif selama proses kognitif pembelajaran. Secara sederhana metakognisi didefinsikan sebagai "berpikir dalam berpikir". Metakognisi terdiri dari dua komponen yakni pengetahuan dan pengaturan. Pengetahuan metakognitif terdiri dari pengetahuan diri sendiri sebagai siswa dan faktor-faktor yang dapat mempengaruhinya, pengetahuan tentang strategi, pengetahuan tentang kapan dan mengapa menggunakan strategi. Pengaturan metakognitif adalah pangetahuan seseorang tentang kognisi dan termasuk pada aktivitas perencanaan, kesadaran pemahaman dan tugas-tugas kinerja, evaluasi dari efektivitas proses, dan strategi (Amir dkk, 2018).

Schoenfeld (Rochmad, 2008) mendefinisikan metakognisi sebagai berikut: "metacognition is thinking about our thingking and compires of the following three important aspect: knowledge about our own thought processes, control or selfregulation, and belief and intuition". Artinya metakognisi sebagai proses berpikir tentang pikiran kita sendiri yang merupakan interaksi antara tiga aspek penting yaitu: pengetahuan tentang proses berpikir kita sendiri, pengontrolan atau pengaturan diri, serta keyakinan dan intuisi. Metakognisi tidak sama dengan kognisi, misalnya keterampilan yang digunakan untuk membaca suatu soal berbeda dengan memonitor pemahaman terhadap soal tersebut. Beberapa hal yang dapat dilakukan guru untuk menolong siswa mengembangkan kesadaran metakognisinya antara lain melalui situasi kegiatankegiatan berikut: 1) ajukan pertanyaan yang berfokus pada apa dan mengapa; 2) kembangkan berbagai aspek problem solving yang dapat meningkatkan prestasi siswa; (3) dalam proses pemecahan suatu masalah, siswa harus secara nyata melakukannya secara mandiri atau berkelompok sehingga mereka merasakan langsung liku-liku proses untuk menuju pada suatu penyelesaian (An dan Li Cao, 2014). Strategi metakognitif disediakan untuk membimbing peserta didik dalam bekerjasama, maka peserta didik dapat menerapkan strategi metakognitif oleh mereka sendiri, serta mereka perlu dukungan eksternal berupa scaffolding untuk melakukannya. Sehingga ada teoritik dan empirik konsensus secara luas menyatakan bahwa pengaruh metakognisi pada hasil belajar sangat terkait dengan scaffolding (Jbeili, 2012).

Bahan ajar merupakan suatu perangkat pembelajaran harus mencerminkan pendekatan yang akan kita gunakan dan tujuan atau kompetensi apa yang diharapkan (Nindiasari, 2011). Pada pembelajaran di Perguruan Tinggi, bahan ajar menjadi alat pendukung pembelajaran di kelas. Bahan ajar tersebut harus mampu dipahami oleh mahasiswa untuk menimbulkan ketertarikan membaca serta mampu melibatkan kesadaran proses berpikirnya. Bahan ajar yang melibatkan proses berpikir memerlukan keterlibatan keterampilan metakognisi. Dengan melibatkan keterampilan metakognisi pada pembelajaran dikelas dapat mengacu pada proses yang digunakan untuk merencanakan, memantau dan mengevaluasi pemahaman dan kinerja seseorang (Zubaidah, 2016).

Tujuan penelitian ini yakni menghasilkan bahan ajar berbasis keterampilan metakognisi untuk meningkatkan kemampuan literasi matematis mahasiswa. Tujuan lainnya pembelajar dalam hal ini mahasiswa dapat dengan baik melibatkan proses berpikirnya sehingga mampu melakukan proses berfikir matematis berupa mengkomunikasikan, menalar, menyelesaikan masalah, dan melakukan representasi matematis dalam meningkatkan kemampuan literasi matematisnya.

\section{Metode Penelitian}

Penelitian ini menggunakan model pengembangan ADDIE. Dimulai tahap analisis dengan melakukan tes awal kemampuan literasi matematis mahasiswa menggunakan alat tes yang telah disusun. Setelah diperoleh data awal kemampuan literasi matematis mahasiswa yang rendah selanjutnya dilakukan tahap desain bahan ajar berbasis keterampilan metakognisi. 
Selanjutnya melakukan validasi bahan ajar tersebut kepada ahli yang telah ditentukan. Setelah divalidasi, selanjutnya tahap implementasi yakni bahan ajar diterapkan pada pembelajaran dikelas dengan melibatkan mahasiswa kelas A8 pada materi kuliah yang telah ditentukan. Pada tahap evaluasi, peneliti mengukur peningkatan kemampuan literasi matematis mahasiswa dengan melakukan posttest dan menganalisis seberapa besar kontribusi bahan ajar dalam penelitian ini.

Berikut alur penelitian pengembangan ini disajikan dalam bentuk Gambar 1.

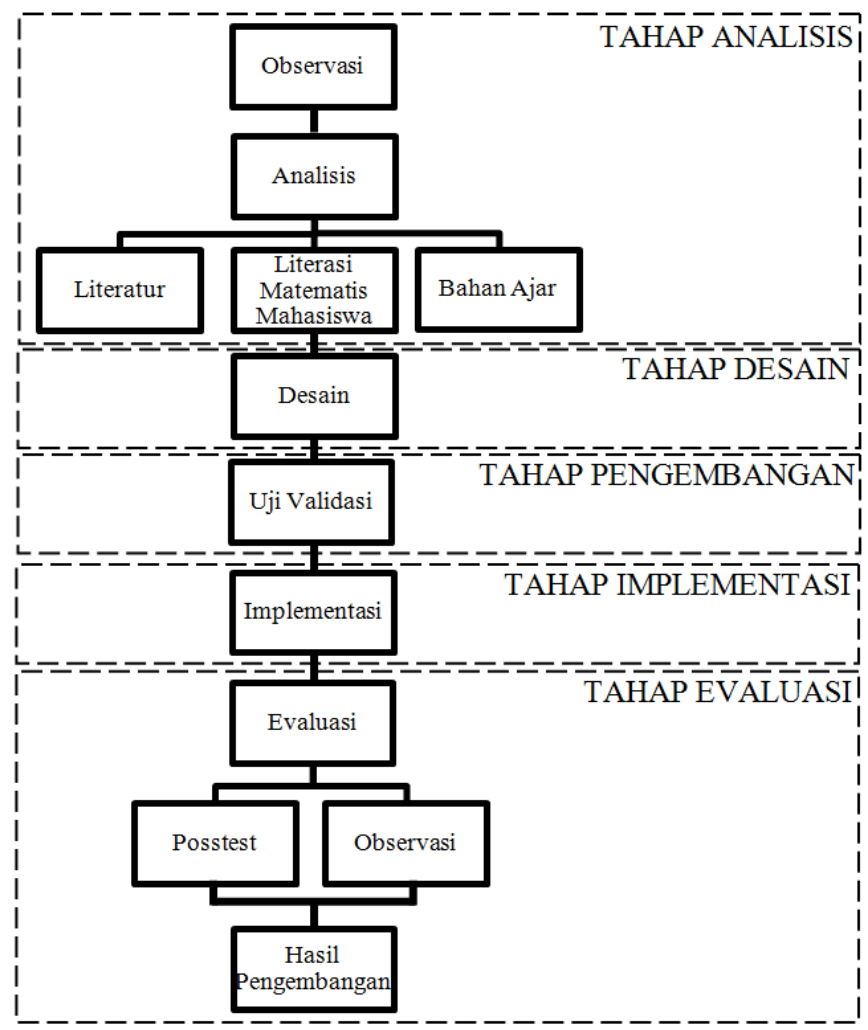

Gambar 1. Prosedur Pemngembangan Bahan Ajar

Teknik analisis validasi bahan ajar dilakukan menggunakan teknik analisis data presentase. Rumus yang digunakan dalam teknik analisis berikut.

Keterangan:

$$
\text { Persentase }(P)=\frac{\sum X}{X_{\text {maks }}} \times 100 \%
$$

$\sum X=$ jumlah nilai

$X_{\text {maks }}=$ nilai maksimal

Hasil perhitungan persentase di atas akan dibandingkan dengan tabel kriteria berikut.
Tabel I

Kriteria Analisis Angket Validasi Ahli

\begin{tabular}{cc}
\hline Persentase & Kriteria \\
\hline$P \geq 85$ & Baik Sekali \\
$75 \leq P<85$ & Baik \\
$60 \leq P<75$ & Cukup \\
$40 \leq P<60$ & Kurang \\
$0 \leq P<40$ & Gagal \\
\hline
\end{tabular}

Peningkatan kemampuan literasi matematis mahasiswa diukur menggunakan perhitungan gain score. Dengan menggunakan nilai tes kemampuan literasi matematis yakni nilai pretest dan postest kemampuan literasi matematis yang telah didapat, selanjutnya diolah menggunakan rumus sebagai berikut

Keterangan:

$$
g=\frac{X_{2}-X_{1}}{X_{\text {maks }}-X_{1}}
$$

$X_{1}=$ nilai pretest

$X_{2}=$ nilai postest

$X_{\text {maks }}=$ nilai maksimal

Selanjutnya hasil perhitungan di atas dibandingkan melalui tabel berikut untuk mendapatkan kriteria peningkatan kemampuan literasi matematis mahasiswa.

Tabel II

Kriteria gain score

\begin{tabular}{cc}
\hline Gain Score & Kriteria \\
\hline$g \geq 0,7$ & Tinggi \\
$0,3 \leq g<0,7$ & Sedang \\
$g<0,3$ & Rendah \\
\hline
\end{tabular}

\section{HASIL DAN PEMBAHASAN}

Bahan ajar ini dikembangkan melaui 5 tahap berdasarkan model pengembangan ADDIE, yaitu Analysis, Design, Development, Implementation, dan Evaluation. Setelah melaui kelima tahapan tersebut, bahan ajar yang dihasilkan berupa bahan ajar pada Mata Kuliah Pembelajaran Matematika SD yang berbasis keterampilan metakognisi dalam meningkatkan kemampuan literasi matematis mahasiswa.

Tahap pertama melakukan analysis. pada tahap ini peneliti melakukan analisis studi kepustakaan berkaitan dengan kemampuan literasi matematis, keterampialan metakognisi dan bahan ajar pada mata kuliah Pembelajaran Matematika SD. Diawali dengan mengumpulkan bahan referensi baik buku, artikel dari jurnal nasional dan internasional. Dengan mengumpulkan referensi yang berkaitan dengan topik 
penelitian, menjadikan modal awal untuk melanjutkan pada tahap berikutnya.

Tahap kedua melakukan design. Setelah diperoleh literatur yang diperlukan, peneliti melanjutkan dengan membuat bahan ajar berbasis keterampilan metakognisi pada materi Pembelajaran Pecahan pada Matematika SD. Bahan ajar dibuat sedemikian rupa, yakni pada tiap langkahnya peneliti sisipkan pertanyaan atau scaffolding. Hal ini dilakukan supaya pengguna dapat melibatkan keterampilan metakognisinya. Kemudian pada halaman akhir bahan ajar, peneliti memberikan soal tes untuk mengukur kemampuan literasi matematis mahasiswa.

Tahap ketiga melakukan development. Setelah draft bahan ajar selesai dibuat, selanjutnya pada tahap ini peneliti meminta dua orang ahli untuk melakukan validasi. Ahli tersebut memvalidasi bahan ajar yang terdiri dari aspek isi, bahasa, dan tampilan. Hasilnya berupa revisi dan masukan ahli yang berkaitan dengan perbaikan kalimat tanya bantu untuk memunculkan keterampilan metakognisi, serta isi materi dalam penekanan pemahaman konsep pada materi pecahan. Kemudian menggunakan pendekatan saintifik yang lebih menekankan pada keterampilan metakognisi dengan melibatkan kemampuan mengamati, menanya, mencoba, dan mengkomunikasikan. Hasil validasi ahli secara keseluruhan menyatakan layak untuk digunakan pada tahap selanjutnya, secara rata-rata hasil disajikan pada tebel berikut.

Tabel III

\begin{tabular}{ccc}
\multicolumn{3}{c}{ Hasil Angket Validasi Ahli } \\
\hline Aspek & Presentase & Kriteria \\
\hline Isi & $78 \%$ & Baik \\
Bahasa & $84 \%$ & Baik Sekali \\
Tampilan & $86 \%$ & Baik Sekali \\
Rata-rata & $82,67 \%$ & Baik Sekali \\
\hline
\end{tabular}

Tahap keempat melakukan implementation. Bahan ajar yang telah divalidasi oleh ahli dan direkomendasikan untuk digunakan pada tahap selanjutnya, kemudian siap digunakan untuk diimplementasikan kepada mahasiswa. Pada tahap ini, uji bahan ajar secara terbatas dilakukan kepada 26 mahasiswa prodi PGSD kelas A8. Tiap bahan ajar digunakan untuk satu kali pertemuan pembelajaran.

Tahap akhir pada penelitian ini dengan melakukan evaluation. Pada tahap ini hasil tes kemampuan literasi matematis yang mencakup pretes dan postes dianalisis, kemudian dilihat peningkatannya. Selain tes akhir, dilakukan juga observasi atas penggunaan bahan ajar berbasis keterampilan metakognisi pada tiap pembelajarannya. Peningkatan kemampuan literasi matematis mahasiswa diperoleh melalui nilai pretest dan postest, berikut tabel hasil perhitungan yang diperoleh.

Tabel IV

Hasil Pretest dan Postest Kemampuan Literasi Matematis Mahasiswa

\begin{tabular}{lc}
\hline \multicolumn{1}{c}{ Keterangan } & Hasil \\
\hline Rata-Rata Nilai Pretest $\left(X_{1}\right)$ & 60,2 \\
Rata-Rata Nilai Postest $\left(X_{2}\right)$ & 82,7 \\
Skor Maksimal $\left(X_{\text {maks }}\right)$ & 100 \\
\hline
\end{tabular}

Dari hasil tabel di atas diperoleh perhitungan Gain Score sebagai berikut:

$$
\begin{gathered}
g=\frac{82,7-60,2}{100-60,2} \\
g=0,57
\end{gathered}
$$

Dari hasil perhitungan di atas, diperoleh nilai rata-rata peningkatan kemampuan literasi matematis mahasiswa sebesar 0,57 dengan kriteria sedang. Peningkatan kemempuan literasi ini dikarenakan mahasiswa pada pembelajaran menggunakan bahan ajar berbasis keterampilan metakognisi. Dimana pada pembelajarannya mahasiswa dengan sadar, berdasarkan pertanyaan-pertanyaan yang muncul pada bahan ajar membantu mahasiswa untik sadar memahami lebih dalam pada masalah yang muncul. Kemudian sadar akan menyiapkan dan mencari rencana untuk menyelesaikan masalah, sehingga lebih maksimalnya proses merencanakan dan menyelesaikan masalah dengan melakukan rencana yang telah disiapkkan. Pada akhirnya mereka dengan kesadaran kognisinya mengecek dan mengevaluasi pada hasil yang diperoleh untuk menentukan apakan jawaban yang telah mereka dapat tepat. Hal ini dapat terlihat pada jawaban serta alasan terakhir pada proses evaluasi jawaban pada bahan ajar.

Pembelajaran yang melibatkan keterampilan metakognisi pada bahan ajar dapat meningkatkan kemampuan literasi matematis mahasiswa. Hasil ini selaras dengan apa yang diungkapkan oleh Webb, Franke, Chan, Freund, \& Shein (Jbeili, 2012:48) bahwa ketika pelajar dilatih untuk menjelaskan pemikiran mereka melalui keterampilan metakognisi dengan mengajukan pertanyaan pada proses belajarnya, itu membantu untuk memperjelas penjelasan mereka, membenarkan strategi penalarandan pemecahan masalah mereka sehingga dapat meningkat. Selanjutnya dengan melibatkan keterampilan metakognisi melaui bahan ajar, membuat pembelajar mampu memahami masalah, menggunakan fakta, aturan, 
algoritma, prosedur dalam matematika untuk memecahkan masalah, menggunakan representasi yang berbeda, memanipulasi informasi, menafsirkan kembali hasil pemecahan masalah yang dihadapi, dan memberikan alasan atau kesimpulan yang didapat (Murod, 2015).

\section{KESIMPULAN}

Berdasarkan penyajian dan temuan di atas, maka dapat ditarik beberapa kesimpulan sebagai berikut.

1. Penelitian pengembangan bahan ajar yang berbasis keterampilan metakognisi menghasilkan bahan ajar pembelajaran matematika pada materi ajar Pembelajaran Pecahan di Sekolah Dasar. Bahan ajar dikembangkan terdiri dari petunjuk, indikator, kompetensi yang dicapai, kegiatan pembelajaran, dan tes kemampuan literasi matematis. Pada tiap langkah-langkah pembelajaran sisipkan pertanyaan atau scaffolding guna melibatkan keterampilan metakognisinya.

2. Berdasarkan validasi ahli secara keseluruhan bahan ajar berbasis keterampilan metakognisi dinyatakan layak untuk digunakan pada tahap selanjutnya, ratarata hasil diperoleh $82,67 \%$ dengan kriteria baik sekali.

3. Terdapat peningkatan kemampuam literasi matematis mahasiswa sebesar 0,57 dengan kriteria sedang. Hasil ini diperoleh nilai selisih antara pretes dan postest setelah diterapkannya bahan ajar berbasis keterampilan metakognisi pada pembelajaran di kelas.

\section{REFERENSI}

Amir, Mohammad Faizan \& Mahardika D. K. W. (2018). Pengembangan Perangkat Pembelajaran Berbasis Masalah Kontekstual untuk Meningkatkan Kemampuan Metakognisi Siswa Sekolah Dasar, Journal of Medives, 2(1), 117-128.

An, Yun-Jo and Li Cao. (2014). Examining the Effects of Metacognitive Scaffolding onStudents' Design Problem Solving and Metacognitive Skills in an Online Environment. MERLOT Jounal of Learning and Teaching, 10(4), 552568.

Jbeili, Ibrahim. (2012). The Effect of Cooperative Learning with Metacognitive Scaffoldingon Mathematics Conceptual Understanding and
Procedural Fluency. InternationalJournal for Research in Education (IJRE), 32: 45-71.

Mahdiansyah dan Rahmawati. (2014).Literasi matematikaa Siswa Jenjang Pendidikan Menengah:Analisis Menggunakan Desain Tes Internasional dengan Konteks Indonesia.JurnalPendidikan dan Kebudayaan, 20(4), 455.

Murod, R. R. (2015). Pendekatan Pembelajaran Metacognitive Scaffolding Dengan Memanfaatkan Multimedia Interaktif Untuk Meningkatkan Literasi Matematis Siswa SMA,(on line). Makalah dalam Seminar Nasional Matematika dan Pendidikan Matematika UNY.

Murtiyasa, B. (2015). Tantangan pembelajaran matematika era global. Form https://publikasiilmiah.ums.ac.id/bitstream/ha ndle/11617/6005/28_47\%20PROF\%20BUDI $\% 20 \mathrm{M} . p d f$

Nindiasari, H. (2011). Pengembangan bahan ajar dan instrumen untuk meningkatkan berpikir reflektif matematis berbasis pendekatan metakognitif pada siswa sekolah menengah atas (SMA). Universitas Sultan Ageng Tirtayasa, Banten ISBN, 978-979.

Rochmad. (2008). Penggunaan Pola Pikir InduktifDeduktif Dalam PembelajaranMatematika Beracuan Konstruktivisme. Makalah telah disampaikan pada SeminarNasional Pendidikan Matematika: Sertifikasi Guru: Meningkatkan Kualitas Matematika di Indonesia. Di Kampus Pascasarjana UNNES Semarang, tanggal 16 Januari 2008.

Sari, Rosalia Hera Novita. (2015). Literasi Matematika: Apa, Mengapa, dan Bagaimana. Prosiding Seminar Nasional Matematika dan Pendidikan Matematika UN,713-720.(Online) http://seminar.uny.ac.id/semnasmatematika/si tes/seminar.uny.ac.id.semnasmatematika/files /banner/PM-102.pdf

Setiawan, B., \& Tandililing, E. (2016). Pembelajaran Dengan PBL Berstruktur Metakognisi Untuk Meningkatan Kemampuan Problem Solving dan Literasi matematis Mahasiswa. Jurnal Pendidikan dan Pembelajaran, 5(12).

Zubaidah, S. (2016, December). Keterampilan abad ke21: Keterampilan yang diajarkan melalui pembelajaran. In Seminar Nasional Pendidikan dengan tema "Isu-isu Strategis Pembelajaran MIPA Abad (Vol. 21, No. 10). 